\title{
Polymerase chain reaction for the evaluation of Schistosoma mansoni infection in two low endemicity areas of Minas Gerais, Brazil
}

\author{
Gabriel Costa de Carvalho ${ }^{1 /+}$, Letícia Helena dos Santos Marques ${ }^{2}$, \\ Luciana Inácia Gomes², Ana Rabello², Luiz Cláudio Ribeiro³, Kezia Katiane Gorza Scopel', \\ Sandra Helena Cerrato Tibiriçá ${ }^{4}$, Elaine Soares Coimbra', Clarice Abramo ${ }^{1}$
}

\author{
${ }^{1}$ Departamento de Parasitologia, Microbiologia e Imunologia ${ }^{4}$ Faculdade de Medicina ${ }^{3}$ Departamento de Estatística, \\ Universidade Federal de Juiz de Fora, Juiz de Fora, MG, Brasil ²Centro de Pesquisas René Rachou-Fiocruz, Belo Horizonte, MG, Brasil
}

\begin{abstract}
This study aimed to evaluate the occurrence of schistosomiasis in areas with low endemicity using polymerase chain reaction (PCR) as a diagnostic method. We analysed faecal samples from 219 individuals residing in Piau and Coronel Pacheco, state of Minas Gerais, Brazil, using a single faecal sample from each individual and two slides of the Kato-Katz technique as a gold standard. Fifteen out of the 219 samples were positive with both methods of diagnosis. One sample was diagnosed as positive by the Kato-Katz technique only and 61 were diagnosed only by PCR. The positivity rates were $7.3 \%$ with the Kato-Katz method and $34.7 \%$ with PCR. When both techniques were assumed to have 100\% specificity and positive individuals were identified by both methods, the sensitivity of the Kato-Katz method was $20.8 \%$ and the PCR sensitivity was $98.7 \%$. The Kappa index between the two techniques was 0.234 , suggesting weak agreement. The assessment of a single faecal sample by PCR detected more cases of infection than the analysis of one sample with two slides using the Kato-Katz technique, suggesting that PCR can be a useful diagnostic tool, particularly in areas with low endemicity.
\end{abstract}

Key words: schistosomiasis - Kato-Katz - PCR - diagnosis - low endemicity

Schistosomiasis is an endemic disease that affects over 200 million people worldwide. Approximately 700 million people live in an endemic area in 76 countries, which has resulted in many economic and public health problems (WHO 2008). In Brazil, it is estimated that six-eight million people are infected and 26 million are at risk in areas of Schistosoma mansoni infection. This disease is irregularly distributed in the state of Minas Gerais (MG), which has the highest prevalence rate for schistosomiasis in Brazil (do Amaral et al. 2006, WHO 2008, Drummond et al. 2010).

The usefulness of the quantitative Kato-Katz technique makes the diagnosis of schistosomiasis mansoni easy, fast and inexpensive through a quantitative direct examination of eggs in stool samples. Considered the gold standard method by the World Health Organization (WHO 1993), the Kato-Katz technique has superior sensitivity in comparison to other parasitological techniques for S. mansoni eggs (Chaves et al. 1979, Santos et al. 2005, Enk et al. 2008). However, this technique becomes less efficient when the specimens contain a small amount of eggs, as in post-treatment situ-

Financial support: FAPEMIG/PPSUS (EDT-3323/06) (Research and control of schistosomiasis and other intestinal parasites in the Zona da Mata Mineira), CAPES

+ Corresponding author: gabrielbiomed@hotmail.com

Received 7 March 2012

Accepted 8 August 2012 ations and low endemicity areas (De Vlas \& Gryseels 1992, Engels et al. 1997, Kongs et al. 2001, Pontes et al. 2003, Enk et al. 2008).

Piau and Coronel Pacheco are located in MG (IBGE 2010). A case of schistosomal myeloradiculopathy close to these two cities and the presence of the intermediate host Biomphalaria sp. were the factors that motivated this study of schistosomiasis in this region. Previous studies identified the first autochthonous case of schistosomiasis in Piau and other cases in Coronel Pacheco, with prevalence rates of $2 \%$ and $3.1 \%$, respectively. These results made it possible to classify these regions as low endemicity areas (Tibiriçá 2008, Tibiriçá et al. 2009). Nevertheless, the prevalence might be underestimated due to the limitations of the conventional diagnostic method used, the Kato-Katz technique (Katz et al. 1972), in a low-intensity transmission area.

However, polymerase chain reaction (PCR) has recently been employed in the diagnosis of $S$. mansoni and has demonstrated high specificity and sensitivity in the detection of DNA in stool samples from patients in endemic areas (Pontes et al. 2003, Allan et al. 2009, Gomes et al. 2009). This method of diagnosis has been shown to be 10-fold more sensitive than the Kato-Katz technique (Pontes et al. 2002, Rabello et al. 2002).

The aim of this study was to evaluate PCR as a diagnostic method in the low-intensity transmission areas of Piau and Coronel Pacheco.

\section{SUBJECTS, MATERIALS AND METHODS}

Study area - This study was performed in the municipalities of Piau (S21 $30^{\prime} 34^{\prime \prime}$ W43 ${ }^{\circ} 19^{\prime} 22^{\prime \prime}$ ) and Coronel Pacheco (S21 $35^{\prime} 16^{\prime \prime}$ W4315'57'), with areas of 
$192 \mathrm{~km}^{2}$ and $132 \mathrm{~km}^{2}$, respectively. They have 2,457 and 2,973 thousands inhabitants, respectively (IBGE 2007) and both are part of the region known as Zona da Mata Mineira (Drummond et al. 2010). All samples were collected from January-April 2007.

Study population - In a previous study (Tibiriçá 2008), the prevalence of schistosomiasis was determined in Piau (807 individuals; 2\%) and Coronel Pacheco (809 individuals; 3.1\%). In the present study, 129 and 90 individuals were selected from Piau and Coronel Pacheco, respectively. These areas and areas $1 \mathrm{~km}$ further away were chosen because they are known to have a higher risk of infection due to the presence of snails of the genus Biomphalaria sp., natural resources (hydric collections with snails near the populated areas) and individuals infected with $S$. mansoni.

The study group was composed of 219 inhabitants from Piau and Coronel Pacheco; $48.9 \%$ were female and $51.1 \%$ were male. The participant ages ranged from one90 years (mean age $=38$ years). Faecal material was collected by Family Health Program community workers from the two municipalities and sent to the Laboratory of Parasitology at the Institute of Biological Sciences of the Federal University of Juiz de Fora (UFJF), MG, for storage and subsequent analysis. Informed consent was obtained from all adult participants and the parents or legal guardians of the minors. This work was approved by the Ethical Committee in Human Research (CEP) of UFJF (case 172/2006).

Kato-Katz technique - Two slides were prepared from each faecal sample using the Kato-Katz method (Katz et al. 1972).

DNA extraction - Stool samples were collected and stored at $-20^{\circ} \mathrm{C}$ until use and maintained on ice during transportation to the research laboratory. Total DNA was extracted from $500 \mathrm{mg}$ of each faecal sample using the QIAamp DNA Stool Mini Kit (Qiagen GmbH, Hilden, Germany) according to the manufacturer's recommendations and following the DNA Isolation from Large Amounts of Stool and Isolation of DNA from Stool for Pathogen Detection protocols. The concentration and purity of the DNA were determined by absorbance measurements at A260 and A280 using a Nanodrop 2000 spectrophotometer (NanoDrop Technologies, Wilmington, DE).

DNA amplification from S. mansoni - Primers were designed to amplify a highly repetitive $110 \mathrm{bp}$ sequence of S. mansoni (Pontes et al. 2002) that composes approximately $10 \%$ of the parasite genome. To amplify S. mansoni DNA, $5 \mu \mathrm{L}$ of the material extracted from faeces was used as a template and all reactions were performed with a GenePro TC-E 96G Thermal Cycler (Rochester, NY). PCR was performed in a final volume of 20 $\mu \mathrm{L}$ containing the following: $20 \mathrm{mM}$ Tris- $\mathrm{HCl}, \mathrm{pH} 8.4$, $50 \mathrm{mM} \mathrm{KCl}, 1.5 \mathrm{mM} \mathrm{MgCl}, 0.6 \mu \mathrm{M}$ of each primer, $0.3 \mu \mathrm{M}$ of the four dNTPs and 0.75 units of Taq DNA polymerase (Invitrogen). The cycling conditions were the following: $95^{\circ} \mathrm{C}$ for $5 \mathrm{~min}, 35$ cycles of $95^{\circ} \mathrm{C}$ for $40 \mathrm{sec}$ and $63^{\circ} \mathrm{C}$ for $30 \mathrm{sec}$ and an extension step at $72^{\circ} \mathrm{C}$ for 5 min. To prevent carryover contamination, the extraction and amplification of DNA and the preparation of the PCR mixture were conducted in separate environments using sterile and disposable laboratory supplies. Contamination was monitored using negative controls containing water instead of extracted DNA in the amplification reaction and DNA from samples diagnosed as negative through both Kato-Katz and PCR evaluations. The PCR products were subjected to electrophoresis on $6 \%$ polyacrylamide gels and analysed after silver staining.

Amplification of universal bacterial DNA - A DNA extraction kit from Qiagen was used to elute all types of genetic material in the faecal samples from a silica column. Thus, the purpose of the amplification of bacterial DNA in the total DNA samples was to evaluate the efficiency of extraction, particularly in samples negative for S. mansoni after Kato-Katz and PCR evaluation. To this end, $20 \%$ of the DNA samples obtained from different cities were used. Primers were designed to amplify a 1,067 bp sequence of the 16S rDNA gene of bacteria (Ferreira et al. 2010). For amplification, $5 \mu \mathrm{L}$ of the extracted material was used. All reactions were performed with a GenePro TC-E 96G Thermal Cycler (Rochester, NY) in a final volume of $25 \mu \mathrm{L}$ containing $10 \mathrm{mM}$ Tris- $\mathrm{HCl}, \mathrm{pH} 8.4,50 \mathrm{mM}$ $\mathrm{KCl}, 2 \mathrm{mM} \mathrm{MgCl}, 0.4 \mu \mathrm{M}$ of each primer, $0.3 \mu \mathrm{M}$ of each dNTP, $0.1 \mathrm{mg}$ of BSA and $2 \mathrm{U}$ of Platinum Taq DNA polymerase (Invitrogen). The cycling programme, preceded by $5 \mathrm{~min}$ at $95^{\circ} \mathrm{C}$, consisted of 35 cycles at $94^{\circ} \mathrm{C}$ for $1 \mathrm{~min}$, $55^{\circ} \mathrm{C}$ for $1 \mathrm{~min}$ and $72^{\circ} \mathrm{C}$ for $2 \mathrm{~min}$. A final elongation step at $72^{\circ} \mathrm{C}$ for $10 \mathrm{~min}$ was added. The PCR products were subjected to electrophoresis on $6 \%$ polyacrylamide gels and analysed after silver staining.

Statistical analysis - SPSS statistical software package 14.0 (SPSS Inc, Chicago, IL, USA) and Microsoft Excel (2010) were used for data analysis and figure assembly. The results were interpreted with the Kappa index and the levels of agreement were categorised as poor $(<0.20)$, weak $(0.21-0.40)$, moderate $(0.41-0.60)$, good (0.61-0.80) or excellent (0.81-1) according to Landis and Koch (1977).

\section{RESULTS}

The results of the PCR and Kato-Katz techniques showed that 15 out of 219 samples were positive in the two cities using both methods of diagnosis for $S$. mansoni infection. The frequency of positive and negative results was similar between the cities, regardless of the diagnostic technique used. The frequency of Kato-Katz positives was (93.8-91.1\%) and negatives (6.2-8.9\%) while the frequency of PCR positives was (63.6-67.8\%) and negatives (36.4$32.2 \%$ ) in Piau and Coronel Pacheco, respectively. One sample was positive only by the Kato-Katz technique and 61 were positive only by PCR. The positivity rate using the Kato-Katz technique was $7.3 \%$, while it was $34.7 \%$ using PCR. The Kappa coefficient was 0.234 , showing weak agreement between the diagnostic techniques (Table I). The amplification of bacterial DNA in both positive and negative samples using the PCR and Kato-Katz methods demonstrated correct DNA extraction, confirming that negative PCR results occurred because of the absence of $S$. mansoni DNA in the tested samples. 
Two different methods were used to calculate the diagnostic parameters. The Kato-Katz technique was initially considered as the gold standard, providing a sensitivity and specificity of $93.8 \%$ and $70 \%$, respectively, for the PCR technique. The positive predictive value (PPV) of PCR was $19.7 \%$ and the negative predictive value (NPV) was $99.3 \%$. In the second analytic approach, the specificity values of the Kato-Katz and PCR methods were both considered to be $100 \%$; as such, a person with a positive result with both methods was defined as infected. The Kato-Katz sensitivity decreased in the second analysis, whereas the PCR sensitivity increased by $4.9 \%$ to a value of $98.7 \%$. The PPV of PCR increased to $100 \%$ and the NPV remained at $99.3 \%$. Each form of presentation of the estimated values is shown in Table II.

The frequency of positive individuals was assessed considering the technique used and the age range in both cities, as shown on Figure. The PCR positivity rate was higher than for the Kato-Katz method. Considering the

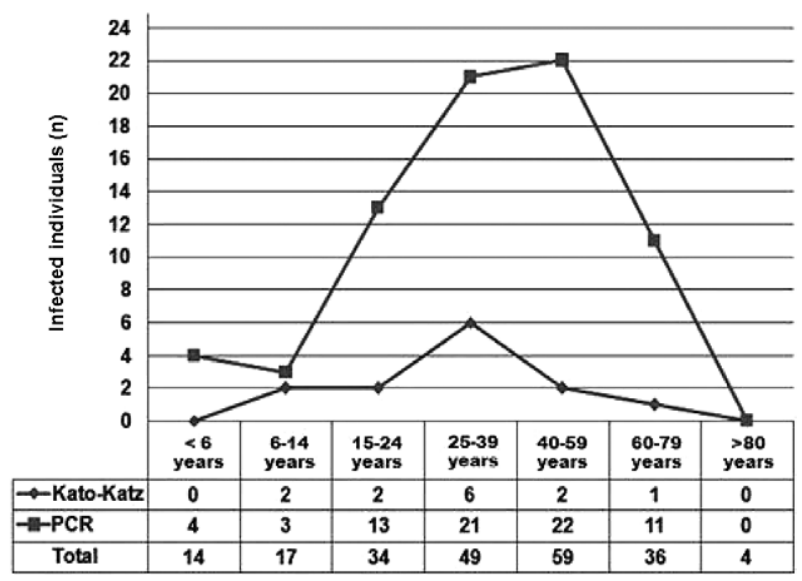

Number of Schistosoma mansoni infected individuals by pre-established age groups in Piau and Coronel Pacheco, state of Minas Gerais, Brazil. PCR: polymerase chain reaction.

TABLE I

Comparative evaluation of polymerase chain reaction (PCR) and Kato-Katz (1 sample, 2 slides) for the diagnosis of Schistosoma mansoni infection in Piau and Coronel Pacheco, state of Minas Gerais, Brazil

\begin{tabular}{lccc}
\hline & \multicolumn{3}{c}{ Kato-Katz } \\
\cline { 2 - 3 } PCR & $\begin{array}{c}\text { Positive } \\
\text { (n) }\end{array}$ & $\begin{array}{c}\text { Negative } \\
(\mathrm{n})\end{array}$ & $\begin{array}{c}\text { Total } \\
\text { (n) }\end{array}$ \\
\hline Positive & 15 & 61 & $76(34.7)^{a}$ \\
Negative & 1 & 142 & 143 \\
\hline Total & $16(7.3)^{b}$ & 203 & 219 \\
\hline
\end{tabular}

$a, b$ : the positive rate (in percentage) was calculated on the total of 219 samples. Kappa index $=0.234$. total number of individuals per age group, individuals aged 25-39 and 40-59 years were more frequently positive when PCR was used for diagnosis.

This study also made a descriptive association between the number of positive cases among residents who were part of the same family and the diagnostic method used. In total, out of 74 families analysed, 11 had a positive family member using the Kato-Katz technique, while 46 had a positive family member using PCR (Table III). It is important to note that residents of the same family lived in the same household or nearby.

\section{DISCUSSION}

This work analysed PCR as a diagnostic technique for schistosomiasis in regions with low endemicity. The positivity rates were $7.3 \%$ and $34.7 \%$ using the KatoKatz and PCR techniques, respectively. By showing the high sensitivity of this method, these results suggest the importance of using this tool for the diagnosis of this parasitic disease in low endemicity regions. PCR also detected a higher number of positive cases among residents in the same family. Therefore, the number of infected individuals in one family may be underestimated.

\section{TABLE II}

Evaluation of the Kato-Katz (KK) and polymerase chain reaction (PCR) techniques for diagnosis of Schistosoma mansoni infection

\begin{tabular}{lcccccccc}
\hline & \multicolumn{2}{c}{$\begin{array}{c}\text { Sensitivity } \\
(\%)\end{array}$} & \multicolumn{2}{c}{$\begin{array}{c}\text { Specificity } \\
(\%)\end{array}$} & \multicolumn{2}{c}{$\begin{array}{c}\text { PPV } \\
(\%)\end{array}$} & \multicolumn{2}{c}{$\begin{array}{c}\text { NPV } \\
(\%)\end{array}$} \\
\cline { 2 - 9 } & A & B & A & B & A & B & A & B \\
\hline KK & 100 & 20.8 & 100 & 100 & 100 & 100 & 100 & 70 \\
PCR & 93.8 & 98.7 & 70 & 100 & 19.7 & 100 & 99.3 & 99.3 \\
\hline
\end{tabular}

A: values calculated using the $\mathrm{KK}$ results as the gold standard of diagnosis; B: values calculated assuming 100\% specificity for both methods; NPV: negative predictive value; PPV: positive predictive value.

\section{TABLE III}

Number of positive cases for Schistosoma mansoni infection in the same family using the Kato-Katz (KK) methods and polymerase chain reaction (PCR)

\begin{tabular}{lcccc}
\hline & & \multicolumn{3}{c}{$\begin{array}{c}\text { Positive families } \\
\text { (n) }\end{array}$} \\
\cline { 3 - 5 } Method & $\begin{array}{c}\text { Negative } \\
\text { families } \\
\text { (n) }\end{array}$ & $\begin{array}{c}\text { 1 } \\
\text { Individual }\end{array}$ & $\begin{array}{c}2 \\
\text { Individuals }\end{array}$ & $\begin{array}{c}3 \\
\text { Individuals }\end{array}$ \\
\hline KK & 63 & 9 & 1 & 1 \\
PCR & 28 & 30 & 9 & 7 \\
\hline
\end{tabular}

total number of families: 74 . 
Pontes et al. (2003) showed that PCR diagnosed more patients using only one faecal sample than the KatoKatz technique did using three samples. The detection limit for $S$. mansoni eggs by the Kato-Katz technique is 20 eggs/gram of faeces (Katz et al. 1972) and the minimum detectable amount of DNA tested by Pontes et al. (2002) was $1 \mathrm{fg}$.

The Kappa index of 0.234 in the two cities demonstrated a weak level of agreement between the two methods of diagnosis. Therefore, the two methods do not agree with each other in positive or negative results. PCR demonstrated a higher rate of positivity (34.7\%) than the Kato-Katz method with two slides of one faecal sample (7.3\%). The low Kappa index is most likely related to the gold standard chosen (only 2 Kato-Katz slides). Pontes et al. (2003) analysed two slides of three samples using the Kato-Katz method and compared the results to PCR. They demonstrated a Kappa index of 0.8 (excellent) for 194 individuals evaluated in Comercinho, a city endemic for schistosomiasis in MG. Gomes et al. (2009) calculated a rate of 0.51 (moderate) between the Kato-Katz and PCR techniques after evaluating 67 residents in the city of Chonin de Cima, another district with endemic schistosomiasis in the same state, by analysing six slides of one faecal sample.

Our data are in accordance with those of Enk et al. (2008), which highlighted that scanning two slides from a single faecal sample for diagnosis is insufficient to estimate the true prevalence.

Tibiriçá (2008) demonstrated a higher prevalence of S. mansoni in young adults of both sexes (25-39 years), which was mainly associated with farm work and obligatory passage through water collections, followed by recreation, particularly swimming in rivers and streams. School children had a lower prevalence, indicating that they are not suitable as a screening population in epidemiological surveys in areas characterised by low endemicity. In our work, we found that positive results were more frequent in individuals aged 25-39 and 40-59 years when PCR was used for diagnosis. Together, these results question the choice of the use of school children as a screening population in low endemicity areas.

The assessment of a single faecal sample by PCR detected more cases of infection than the analysis of one sample with two slides using the Kato-Katz technique, suggesting that PCR can be a useful diagnostic tool, particularly in areas with low endemicity.

\section{ACKNOWLEDGEMENTS}

To GRS, for the support, collection of samples and KatoKatz analyses, and to the Family Health Program workers of each municipality, for the strong commitment to the collection of samples from each family.

\section{REFERENCES}

Allan F, Rollinson D, Smith JE, Dunn AM 2009. Host choice and penetration by Schistosoma. J Helminthol 83: 33-38.

do Amaral RS, Tauil PL, Lima DD, Engels D 2006. An analysis of the impact of the Schistosomiasis Control Programme in Brazil. Mem Inst Oswaldo Cruz 101 (Suppl. I): 79-85.

Chaves A, Alcântara OS, Carvalho OS, Santos JS 1979. Estudo comparativo dos métodos coprológicos de Lutz, Kato-Katz e Faust modificado. Rev Saude Publica 13: 348-352.
De Vlas SJ, Gryseels B 1992. Underestimation of Schistosoma mansoni prevalences. Parasitol Today 8: 274-277.

Drummond SC, Pereira SRS, Silva LCS, Antunes CMF, Lambertucci JR 2010. Schistosomiasis control program in the state of Minas Gerais in Brazil. Mem Inst Oswaldo Cruz 105: 519-523.

Engels D, Nahimana S, De vlas SJ, Gryseels B 1997. Variation in weight of stool samples prepared by the Kato-Katz method and its implications. Trop Med Int Health 2: 265-271.

Enk MJ, Lima AC, Drummond SC, Schall VT, Coelho PM 2008. The effect of the number of stool samples on the observed prevalence and the infection intensity with Schistosoma mansoni among a population in an area of low transmission. Acta Trop 108: 222-228.

Ferreira DP, Silva VL, Guimarães DA, Coelho CM, Zauli DAG, Farias LM, Carvalho MAR, Diniz CG 2010. Distribution, detection of enterotoxigenic strains and antimicrobial drug susceptibility patterns of bacteroides fragilis group in diarrheic and non-diarrheic feces from Brazilian infants. Brazi J Microbiol 41: 603-611.

Gomes LI, Marques LHS, Enk MJ, Oliveira MC, Coelho PMZ, Rabello A 2009. Development and evaluation of a sensitive PCRELISA system for detection of Schistosoma infection in feces. PLoS Negl Trop Dis 4: 664.

IBGE - Instituto Brasileiro de Geografia e Estatística 2007. Censo demográfico 2007. Available from: ibge.gov.br/cidadesat/topwindow.htm?1.

IBGE - Instituto Brasileiro de Geografia e Estatística 2010. Censo demográfico 2010: características da população e dos domicílios. Resultados do universo. Available from: ibge.gov.br/home/ estatística/populacao/censo2000/default.shtm.

Katz N, Chaves A, Pellegrino J 1972. A simple device for quantitative stool thick-smear technique in Schistosomiasis mansoni. Rev Inst Med Trop Sao Paulo 14: 397-400.

Kongs A, Marks G, Verle P, Stuyft V 2001. The unreliability of the Kato-Katz technique limits its usefulness for evaluating $S$. mansoni infections. Trop Med Int Health 6: 163-169.

Landis JR, Koch GG 1977. The measurement of observer agreement for categorical data. Biometrics 33: 159-174.

Pontes LA, Dias-Neto E, Rabello A 2002. Detection by polymerase chain reaction of Schistosoma mansoni DNA in human serum and feces. Am J Trop Med Hyg 66: 157-162.

Pontes LA, Oliveira MC, Katz N, Dias-Neto E, Rabello A 2003. Comparison of a polymerase chain reaction and the Kato-Katz technique for diagnosing infection with Schistosoma mansoni. Am J Trop Med Hyg 68: 652-656.

Rabello A, Pontes LA, Dias-Neto E 2002. Recent advances in the diagnosis of Schistosoma infection: the detection of parasite DNA. Mem Inst Oswaldo Cruz 97 (Suppl. I): 171-172.

Santos FL, Cerqueira EJ, Soares NM 2005. Comparison of the thick smear and Kato-Katz techniques for diagnosis of intestinal helminth infections. Rev Soc Bras Med Trop 38: 196-198.

Tibiriçá SHC 2008. Epidemiologia da esquistossomose em três municipios da microrregião de Juiz de Fora, Minas Gerais, PhD Thesis, Universidade Federal de Juiz de Fora, Juiz de Fora, 124 pp.

Tibiriçá SHC, Abramo C, Simões AS, Pinheiro IO, Ribeiro LC, Coimbra ES 2009. Validação do número de lâminas para realização do método de sedimentação espontânea das fezes. HU Revista 35: 105-110.

WHO - World Health Organization 1993. The control of schistosomiasis. Second report of the WHO Expert Committee. WHO Tech Rep Ser 830: 1-86.

WHO - World Health Organization 2008. The social context of schistosomiasis and its control: an introduction and annotated bibliography. Available from: dosei.who.int/uhtbin/cgisirsi/ tLEqou8myB/26990009/5/0. 